\title{
PERLINDUNGAN HUKUM PEMEGANG SAHAM MINORITAS AKIBAT PERBUATAN MELAWAN HUKUM DIREKSI MENURUT UNDANG-UNDANG PERSEROAN TERBATAS
}

\author{
Dwi Tatak Subagiyo \\ Fakultas Hukum Universitas Wijaya Kusuma Surabaya \\ e-mail: tatak subagiyo@yahoo.co.id
}

\begin{abstract}
ABSTRAK
Penelitian ini bertujuan untuk memahami dan menganalisa perlindungan hukum pemegang saham minoritas, akibat hukum bagi Direksi Perseroan yang melakukan perbuatan melawan hukum serta upaya hukum pemegang saham minoritas menurut Undang-Undang Nomor 40 Tahun 2007 tentang Perseroan Terbatas. Berdasarkan hasil penelitian dapat disimpulkan bahwa perlindungan hukum bagi pemegang saham minoritas, antara lain diberikan dalam bentuk penerapan prinsip Good Corporate Governance (pengelolaan perusahaan yang baik). Akibat perbuatan melawan hukum Direksi harus bertanggungjawab mengganti kerugian (Pasal 1365 KUHPerdata) dan apabila terpenuhi unsur pidana, maka Direksi dikenai pidana penjara maupun pidana denda yaitu penggelapan uang dan penipuan (Pasal 372 dan Pasal 378 Kitab UndangUndang Hukum Pidana) bahkan Direksi dapat bertanggungjawab sampai harta pribadinya (Pasal 97 ayat (3) Undang-Undang Nomor 40 Tahun 2007 tentang Perseroan Terbatas).
\end{abstract}

Kata Kunci: Perseroan Terbatas, Pemegang Saham Minoritas, Direksi, Perbuatan Melawan Hukum.

\begin{abstract}
This research was intended to review and analyze the legal protection of minority shareholders, the legal consequences for Director which committed an unlawful act and legal efforts to minority shareholders under the Limited Liability Corporation Act Based on this research, this paper concludes that the legal protection for minority shareholders of the Company can be achieved by applying the principles of Good Corporate Governance (Management of Good Company). As a result of tort law must be held accountable indemnify Director (Article 1365 of the Civil Law Code) and therefore fulfilled criminal element, then the Board of Directors may be subject to imprisonment or criminal fines are wiping money and fraud (Article 372 and Article 378 of the Criminal Law Code) may be responsible to the Director even his private property (Article 97 paragraph (3) of the Limited Liability Corporation Act).
\end{abstract}

Keywords: Limited Company Liability, Minority Shareholders, Director, Unlawful Deeds.

\section{PENDAHULUAN}

Arus globalisasi dan perdagangan bebas sangat mempengaruhi kegiatan perekonomian di Indonesia, hal ini dapat dilihat dengan semakin meningkatnya pendirian badan usaha di wilayah Indonesia. Adapun berbagai bentuk badan usaha yang mendukung kegiatan perekonomian di Indonesia, antara lain yang berbentuk badan hukum adalah Perseroan Terbatas, Yayasan dan Koperasi, dan yang tidak berbentuk badan hukum seperti Firma, Persekutuan Komanditer, Usaha Dagang.
Pengaturan hukum Perseroan Terbatas (yang selanjutnya disebut PT) di Indonesia sudah ada sejak zaman kolonial Belanda yang diatur dalam Buku Kesatu Titel Ketiga Bagian Ketiga Pasal 36 sampai dengan Pasal 56 Kitab Undang-Undang Hukum Dagang (Wetboek van Koophandel voor Indonesie Staatsblad 1847 Nomor 23) dan Maskapai Andil Indonesia (Ordonnantie op de Indonesische Maarschappij op Aandeelen Staatsblad 1939 Nomor 569) yang merupakan peninggalan dari pemerintah 
kolonial Belanda. ${ }^{1}$ Kemudian pengaturan PT dalam KUHD diganti dengan Undang-Undang Nomor 1 Tahun 1995 tentang Perseroan Terbatas, namun dalam perkembangannya ketentuan dalam undang-undang tersebut sudah tidak lagi memenuhi perkembangan hukum dan kemajuan ilmu pengetahuan, teknologi dan informasi yang sudah berkembang begitu pesat khususnya di era globalisasi sekarang ini.

Dengan meningkatnya tuntutan masyarakat akan layanan yang cepat, kepastian hukum, serta tuntutan akan pengembangan dunia usaha yang sesuai dengan prinsip pengelolaan perusahaan yang baik, sehingga menuntut kesempurnaan dalam Undang-Undang Nomor 1 Tahun 1995 tentang Perseroan Terbatas. Dengan demikian Undang-Undang Nomor 1 Tahun 1995 tentang Perseroan Terbatas tersebut diganti dengan Undang-Undang yang baru, yaitu UndangUndang Nomor 40 Tahun 2007 tentang Perseroan Terbatas (untuk selanjutnya juga disebut UUPT).

Bentuk usaha PT banyak diminati oleh masyarakat Indonesia, karena adanya kepastian hukum dalam bentuk pertanggungjawaban yang bersifat terbatas, pemberian kemudahan bagi pemiliknya (pemegang saham) untuk mengalihkan perusahaannya (kepada setiap orang) dengan menjual seluruh saham yang dimilikinya pada perusahaan tersebut. Hal ini disebabkan karena PT merupakan persekutuan modal, didirikan berdasarkan perjanjian, melakukan kegiatan usaha dengan modal dasar yang seluruhnya terbagi dalam saham dan yang lebih penting adanya pemisahan yang jelas antara kepemilikan modal (ownership) dengan kepengurusannya (power). Hal ini disebabkan pemilik dana menginginkan risiko dan biaya sekecil mungkin dalam melakukan kegiatan usaha.

Oleh karena itu setiap melakukan kegiatan usaha harus didukung oleh suatu perjanjian atau kontrak khusus agar risiko yang diperoleh sangat kecil, hal ini disebabkan karena biaya yang diperlukan untuk melakukan kegiatan usaha tidaklah murah terutama pada mekanisme kontrol dari tiap penanaman modal tersebut. Pemilik modal dengan menanam modal melalui Perseroan, berarti hanya membuat satu kontrak, sehingga dapat mengurangi biaya transaksi. Dan risiko investasi hanya terbatas pada dana yang ditanamkan saja, sedangkan mekanisme kontrol diserahkan pada hukum Perseroan dan peraturan

\footnotetext{
${ }^{1}$ Rachmadi Usman, Dimensi Hukum Perusahaan Perseroan Terbatas, Alumni, Bandung, 2004, h. 2.
}

perundang-undangan lainnya yang mengatur tentang PT tersebut. ${ }^{2}$

Sebagaimana yang termuat dalam Pasal 1 angka 1 UUPT tentang PT, pengertian Perseroan adalah sebagai badan hukum yang merupakan persekutuan modal, didirikan berdasarkan perjanjian, melakukan kegiatan usaha dengan modal dasar yang seluruhnya terbagi dalam saham, dan memenuhi persyaratan yang ditetapkan dalam undang-undang ini serta peraturan pelaksanaannya. Adapun modal dalam Perseroan terdiri dari 2 (dua) jenis, yaitu modal dasar dan modal ditempatkan atau modal disetor. Untuk menjadikannya sebagai badan hukum PT, sebuah perusahaan harus mengikuti tata cara pendirian, anggaran dasar dan perubahan anggaran dasar, pendaftaran Perseroan dan pengumuman sebagaimana yang diatur dalam UUPT.

Sebagai badan hukum, maka pendirian Perseroan harus memenuhi syarat: Didirikan oleh 2 (dua) orang atau lebih; Setiap pendiri wajib mengambil bagian saham pada saat pendirian Perseroan; Modal dasar minimal Rp 50.000.000,00 (lima puluh juta rupiah) yang terdiri atas seluruh nilai nominal saham, sedangkan paling sedikit $25 \%$ (dua puluh lima persen) dari modal dasar harus ditempatkan dan disetor penuh; Dalam pembuatan akta pendirian, pendiri dapat diwakili oleh orang lain berdasarkan surat kuasa; dan Didirikan dengan akta notaris dalam bahasa Indonesia.

Dari persyaratan tersebut terlihat jelas peranan penting modal dalam pendirian suatu PT, hal ini berarti bahwa suatu Perseroan merupakan kumpulan akumulasi dari modal. Modal dasar suatu Perseroan itu sendiri terdiri atas seluruh nilai nominal saham sehingga tidaklah berlebihan apabila dikatakan pemegang saham merupakan salah satu pihak yang memiliki kepentingan (stakeholder) dalam suatu PT di samping stakeholder yang lain seperti pekerja, kreditor, investor, konsumen ataupun masyarakat secara keseluruhan. Bahkan lebih dari itu para pemegang saham dalam suatu PT juga merupakan pihak yang membawa dana ke dalam perusahaan.

Pemegang saham dikatakan sebagai pemilik PT, karena saham merupakan penyertaan modal di suatu PT. Dengan demikian, besarnya pemilikan seorang pemegang saham atas Perseroan ditentukan

\footnotetext{
${ }^{2}$ Chatamarrasjid, Menyingkap Tabir Perseroan (Piercing The Corporate Veil) Kapita Selekta Hukum Perusahaan, Citra Aditya Bakti, Bandung, 1990, h. 1.
} 
besarnya penyertaan yang bersangkutan terhadap modal Perseroan. Untuk membuktikan kepemilikan saham, Perseroan mengeluarkan surat saham sebagai bukti kepemilikan atas suatu saham atau pemilikan sejumlah saham. Adapun hak dari seorang pemilik saham itu adalah Menghadiri dan mengeluarkan suara dalam Rapat Umum Pemegang Saham (selanjutnya disebut (RUPS), dan Menerima pembayaran deviden dan sisa kekayaan hasil likuidasi, serta Menjalankan hak lainnya berdasarkan UUPT.

PT merupakan subyek hukum yang berstatus badan hukum yang mempunyai ciri utama, yaitu: adanya pemisahan antara harta kekayaan badan hukum dan pribadi para pemegang saham, maksudnya setiap perbuatan yang dilakukan oleh suatu badan hukum hanya badan hukum sendiri yang bertanggungjawab, sedangkan para pemegang saham tidak bertanggungjawab, kecuali sebatas nilai saham yang dimasukkan dalam Perseroan; dan tanggung jawab yang dimiliki terbatas bagi para pemegang saham, Direksi dan Komisaris, dimana hal ini diatur pada UUPT, sebagaimana dikemukakan di bawah ini:

Pertama, Pasal 3 ayat (1) UUPT menegaskan Pemegang saham Perseroan tidak bertanggungjawab secara pribadi terhadap perikatan yang dibuat atas nama Perseroan dan tidak bertanggungjawab atas kerugian Perseroan melebihi saham yang dimiliki.

Kedua, Pasal 92 ayat (1) UUPT menegaskan bahwa Direksi menjalankan pengurusan Perseroan untuk kepentingan Perseroan dan sesuai dengan maksud dan tujuan Perseroan.

Ketiga, Pasal 97 ayat (1) dan (2) UUPT menegaskan bahwa: a. Direksi bertanggungjawab atas pengurusan Perseroan sebagaimana dimaksud dalam Pasal 92 ayat (1); b. Pengurusan sebagaimana dimaksud pada ayat (1), wajib dilaksanakan setiap anggota Direksi dengan itikad baik dan penuh tanggung jawab.

Keempat, Pasal 108 ayat (1) UUPT menegaskan bahwa Dewan Komisaris melakukan pengawasan atas kebijakan pengurusan, jalannya pengurusan pada umumnya, baik mengenai Perseroan maupun usaha Perseroan, dan memberi nasihat kepada Direksi.

Kelima, Pasal 114 ayat (1) dan (2) UUPT menegaskan: a. Dewan Komisaris bertanggungjawab atas pengawasan Perseroan sebagaimana dimaksud dalam Pasal 108 ayat (1); b. Setiap anggota Dewan
Komisaris wajib dengan itikad baik, kehati-hatian, dan bertanggungjawab dalam menjalankan tugas pengawasan dan pemberian nasihat kepada Direksi sebagaimana dimaksud dalam Pasal 108 ayat (1) untuk kepentingan Perseroan dan sesuai dengan maksud dan tujuan Perseroan.

Meskipun sudah diatur secara jelas mengenai tanggung jawab dari masing-masing organ-organ Perseroan dan juga pemegang saham, dalam praktiknya sering timbul perselisihan di antara organ Perseroan dengan pemegang saham atau bisa terjadi di antara pemegang saham sendiri. Perbedaan antara pemegang saham mayoritas dengan pemegang saham minoritas adalah dalam hal jumlah kepemilikan saham, sehingga sering berlaku Prinsip Mayoritas yang menyebabkan pemegang saham minoritas berada pada posisi yang lemah dalam menegakkan kepentingan dan haknya, yang tidak mampu menghadapi tindakan Direksi atau Komisaris yang merugikan dirinya dan Perseroan yang dapat mempengaruhi secara fisik maupun kepentingan dalam Perseroan. Hal ini karena kedudukan pemegang saham mayoritas identik dengan Direksi atau Komisaris selaku organ Perseroan, baik itu identik secara fisik maupun kepentingan. Disamping itu pemegang saham minoritas tidak mempunyai hak untuk mewakili Perseroan, karena yang hanya boleh dilakukan oleh organ Perseroan saja.

Walau keberadaan UUPT sudah memberikan perlindungan kepada pemegang saham minoritas, namun dalam praktiknya apabila ada hak-hak pemegang saham minoritas yang dirugikan tidaklah mudah untuk meminta pertanggungjawaban dari organ Perseroan, baik langsung pada diri organ Perseroan maupun Perseroan.

Kurangnya transparansi dan akuntabilitas dalam suatu PT yang rentan terhadap konflik dan gugatan. Gugatan mana dapat dilakukan oleh salah satu pemegang saham, termasuk pemegang saham minoritas atau publik yang tidak puas atas semua informasi dan kinerja perusahaan yang dianggap dapat merugikan saham milik masyarakat luas. Oleh karena itu rumusan masalah yang akan diangkat oleh penulis adalah Perlindungan hukum pemegang saham minoritas akibat perbuatan melawan hukum Direksi menurut UUPT dan apa akibat hukum bagi Direksi Perseroan yang melakukan perbuatan melawan hukum serta upaya hukum pemegang saham minoritas menurut UUPT. 


\section{PEMBAHASAN}

\section{Pengertian Pemegang Saham Minoritas}

Dalam UUPT pengertian pemegang saham minoritas tidak diatur secara jelas, namun dalam beberapa pasal tersurat pengaturan mengenai perlindungan hukum terhadap pemegang saham minoritas PT terbuka lebih ditekankan dalam UUPT, dimana dalam undang-undang ini posisi tawar pemegang saham minoritas dalam pengambilan kebijakan suatu perusahaan lebih terperinci dengan hak-hak yang diatur dalam UUPT yaitu antara lain:

Pertama, pada Pasal 61 ayat (1), menegaskan bahwa pemegang saham berhak mengajukan gugatan terhadap Perseroan ke Pengadilan Negeri apabila dirugikan karena tindakan Perseroan yang dianggap tidak adil dan tanpa alasan wajar sebagai akibat keputusan RUPS, Direksi, dan/atau Dewan Komisaris.

Kedua, Pasal 62 menegaskan bahwa pemegang saham berhak meminta kepada Perseroan agar sahamnya dibeli dengan harga yang wajar apabila yang bersangkutan tidak menyetujui tindakan Perseroan yang merugikan pemegang saham atau Perseroan, berupa: Perubahan Anggaran Dasar, Pengalihan atau penjaminan kekayaan Perseroan yang mempunyai nilai lebih dari 50\% (lima puluh persen) kekayaan bersih Perseroan; atau Penggabungan, peleburan, pengambilalihan, atau pemisahan.

Ketiga, Pasal 79 ayat (2) menegaskan Pemegang Saham Perseroan meminta diselenggarakan adanya RUPS, pemegang saham minoritas hanya sekedar mengusulkan tanpa adanya kewenangan untuk memutuskan diadakannya RUPS.

Keempat, Pasal 97 ayat (6) menegaskan bahwa mewakili Perseroan untuk mengajukan gugatan terhadap anggota direksi yang karena kesalahan atau kelalaiannya menimbulkan kerugian terhadap Perseroan.

Kelima, Pasal 114 ayat (6) menegaskan bahwa mewakili Perseroan untuk mengajukan gugatan terhadap anggota dewan komisaris yang karena kesalahan atau kelalaiannya menimbulkan kerugian terhadap Perseroan.

Keenam, Pasal 138 ayat (3) menegaskan bahwa dengan meminta diadakannya pemeriksaan terhadap Perseroan, dalam hal terdapat dugaan bahwa Perseroan, anggota Direksi atau Komisaris Perseroan melakukan perbuatan melawan hukum yang merugikan Perseroan atau pemegang saham atau pihak ketiga. Serta Ketujuh, Pasal 144 ayat (1), mengajukan permohonan pembubaran Perseroan.

Hak-hak pemegang saham minoritas di atas merupakan terobosan yang baru dalam peraturan perundang-undangan di Indonesia dengan lahirnya UUPT, akan tetapi dari hak-hak di atas belum merupakan cerminan perlindungan hukum terhadap pemegang saham minoritas yang sempurna karena aturan mengenai perlindungan hukum pemegang saham minoritas sesuai dengan prinsip Good Corporate Governance masih sulit untuk diterapkan di Indonesia.

Kepentingan antara pemegang saham mayoritas dengan pemegang saham minoritas dalam suatu PT seringkali bertentangan satu sama lain. Minority shareholders atau pemegang saham minoritas tidak jarang hanya dijadikan sebagai pelengkap dalam sebuah perusahaan. Dalam mekanisme pengambilan keputusan di perusahaan dapat dipastikan pemegang saham minoritas ini akan selalu kalah dibanding pemegang saham mayoritas, sebab pola pengambilan keputusan didasarkan atas besarnya prosentase saham yang dimiliki. Keadaan demikian akan semakin parah, jika ternyata pemegang saham mayoritas menggunakan peluang ini untuk mengendalikan perusahaan berdasarkan kepentingannya saja dan tidak mengindahkan kepentingan pemegang saham minoritas.

Seperti yang telah dijelaskan di atas, bahwa pemegang saham minoritas kurang mendapatkan porsi perlindungan hukum dalam pengambilan keputusan di suatu perusahaan, maka ada berbagai kepentingan yang oleh hukum mesti dijaga, antara lain kepentingan-kepentingan seperti kutipan berikut:

Pertama, Pihak pemegang saham minoritas sama sekali tidak berdaya dalam suatu perusahaan karena selalu kalah suara dengan pemegang saham mayoritas dalam rapat umum pemegang saham selaku pemegang kekuasaaan tertinggi.

Kedua, Pihak pemegang saham minoritas tidak mempunyai kewenangan untuk mengurus perusahaan karena tidak mempunyai cukup suara untuk menunjuk Direktur atau Komisarisnya sendiri, atau kalaupun ada kesempatan untuk menunjuk Direktur atau Komisaris, biasanya Direktur atau Komisaris tersebut juga tidak berdaya karena kalah suara dalam rapat-rapat Direksi atau Komisaris. 
Ketiga, Pihak pemegang saham minoritas tidak memiliki kewenangan untuk melakukan hal-hal yang penting baginya, seperti kewenangan untuk mengangkat pegawai perusahaan, menandatangani cek, mereview kontrak perusahaan, dan melakukan tindakan-tindakan penting lainnya.

Keempat, Apakah perusahaan berbisnis secara kurang baik, pihak pemegang saham minoritas umumnya tidak dapat berbuat banyak, kecuali membiarkan perusahaan tersebut terus-menerus merugi sambil mempertaruhkan sahamnya disana.

Kelima, Terutama dalam suatu perusahaan tertutup, saham pihak minoritas umumnya tidak marketable, sehingga sangat sulit dijual ke pihak luar.

Keenam, Prinsip personan in judicio atau capacity standing in court or in judgement, yakni hak untuk mewakili Perseroan, yang hanya boleh dilakukan oleh organ Perseroan. Pemegang saham minoritas tidak boleh melakukan tindakan derivative.

Untuk itu, agar terpenuhinya unsur keadilan, diperlukan suatu keseimbangan sehingga pihak pemegang saham minoritas tetap dapat menikmati haknya selaku mayoritas, termasuk mengatur Perseroan. Dilain pihak, pihak pemegang saham minoritas pun perlu diperhatikan kepentingannya dan tidak bisa begitu saja diabaikan haknya. Untuk menjaga kepentingan di kedua belah pihak, dalam ilmu hukum Perseroan dikenal prinsip Majority Rule minority Protection, yaitu yang memerintah (the ruler) di dalam Perseroan tetap pihak mayoritas, tetapi kekuasaan pihak mayoritas tersebut haruslah dijalankan dengan selalu melindungi (to protect) pihak minoritas. Hal ini jika tidak mendapatkan perhatian dari pemerintah dikhawatirkan akan menganggu iklim investasi dan mematikan investorinvestor kecil.

Pemegang saham (shareholder) adalah seseorang atau badan hukum yang secara sah memiliki satu atau lebih saham pada perusahaan. Para pemegang saham adalah pemilik dari perusahaan tersebut. Pemegang saham diberikan hak khusus tergantung dari jenis saham, termasuk hak untuk memberikan suara (biasanya satu suara per saham yang dimiliki) dalam hal seperti pemilihan Direksi, hak untuk pembagian dari pendapatan perusahaan, hak untuk membeli saham baru yang dikeluarkan oleh perusahaan, dan hak terhadap aset perusahaan pada saat likuidasi perusahaan. Namun, hak pemegang saham terhadap aset perusahaan berada di bawah hak kreditor perusahaan. Ini berarti bahwa pemegang saham biasanya tidak menerima apa pun bila suatu perusahaan yang dilikuidasi setelah kebangkrutan (bila perusahaan tersebut memiliki lebih untuk membayar kreditornya, maka perusahaan tersebut tidak akan bangkrut), meskipun sebuah saham dapat memiliki harga setelah kebangkrutan bila ada kemungkinan bahwa hutang perusahaan akan direstrukturisasi. ${ }^{3}$

\section{Perbuatan Melawan Hukum Direksi Perseroan}

Perbuatan Melawan Hukum diatur dalam Pasal 1365 sampai dengan Pasal 1380 KUHPerdata. Pasal 1365 KUHPerdata menyatakan bahwa tiap perbuatan melanggar hukum yang membawa kerugian kepada seorang lain mewajibkan orang yang karena salahnya menerbitkan kerugian itu dan mengganti kerugian tersebut untuk menentukan perbuatan melawan hukum harus memenuhi syarat-syarat atau unsurunsur sebagai berikut:

Pertama, Adanya Perbuatan Melawan Hukum. Sebelum tahun 1919 pengertian perbuatan melawan hukum dalam Pasal 1365 KUHPerdata mengalami perubahan dengan adanya Arrest LindenbaumCohen Tahun 1919 H.R. 31 Jan Hoetink Nomor 110, dimana hukum diartikan sempit, yaitu hanya berdasarkan undang-undang. Namun pada tahun 1919 dalam Lindenbaum-Cohen Arrest H.R. mengubah pendiriannya, dengan memberikan arti yang luas kepada hukum, yaitu dengan hukum mencakup undang-undang dan hukum yang tidak tertulis, seperti kesusilaan, kepatutan, yang terjadi dalam masyarakat. ${ }^{4}$

Sejak saat itu, ketentuan perbuatan melawan hukum dalam Pasal 1365 KUHPerdata kemudian dipertegas kembali dalam Pasal 1366 KUHPerdata yaitu setiap orang bertanggungjawab tidak hanya untuk kerugian yang ditimbulkan oleh perbuatannya tetapi juga disebabkan oleh kelalaiannya. Kedua pasal tersebut di atas menegaskan bahwa perbuatan melawan hukum tidak saja mencakup suatu perbuatan, tetapi juga mencakup tidak berbuat,

\footnotetext{
3 http://id.wikipedia.org/wiki/Pemegang_saham. diunduh pada hari Rabu, tanggal 16 April 2014 pukul 20.50 WIB.

${ }^{4}$ Badrulzaman, Mariam Darus, Sutan Remy Sjahdeini, Heru Soepraptomo, Faturrahman Djamil, dan Taryana Soenandar, Kompilasi Hukum Perikatan, Dalam Rangka Memperingati Memasuki Masa Purna Bakti Usia 70 Tahun, Citra Aditya Bakti, Bandung, 2001, h. 107.
} 
oleh karena dalam Pasal 1365 KUHPerdata mengatur tentang perbuatan, sedangkan Pasal 1366 KUHPerdata mengatur tentang tidak berbuat, yang harus memenuhi salah satu unsur berikut: Bertentangan dengan hak orang lain; Bertentangan dengan kewajiban hukumnya sendiri; Bertentangan dengan kesusilaan; Bertentangan dengan keharusan (kehati-hatian, kepantasan, kepatutan) yang harus diindahkan dalam pergaulan masyarakat mengenai orang lain atau benda.

Kedua, Adanya unsur kesalahan. Unsur kesalahan dalam hal ini dimaksudkan sebagai perbuatan dan akibat-akibat yang dapat dipertanggungjawabkan kepada si pelaku.

Ketiga, Adanya kerugian. Yaitu kerugian yang timbul karena perbuatan melawan hukum. Tiap perbuatan melawan hukum tidak hanya dapat mengakibatkan kerugian uang saja, tetapi juga dapat menyebabkan kerugian moril atau idiil, yaitu: a. Kerugian materiil adalah kerugian yang nyata-nyata diderita dan keuntungan yang seharusnya diperoleh. Jadi pada umumnya diterima bahwa si pembuat perbuatan yang melawan hukum harus mengganti kerugian tidak hanya untuk kerugian yang nyatanyata diderita, juga keuntungan yang seharusnya diperoleh; b. Kerugian idiil, dimana perbuatan melawan hukum yang menimbulkan kerugian seperti ketakutan, sakit dan kehilangan kesenangan hidup. Sehingga pihak yang dirugikan berhak menuntut ganti rugi tidak hanya kerugian yang telah ia derita pada waktu diajukan tuntutan akan tetapi juga apa yang ia akan derita pada waktu yang akan datang.

Keempat, Terdapat hubungan sebab-akibat. Unsur sebab-akibat dimaksudkan untuk meneliti adalah hubungan kausal antara perbuatan melawan hukum dan kerugian yang ditimbulkan sehingga si pelaku dapat dipertanggungjawabkan.

Adapun tindakan Direksi yang termasuk dalam perbuatan melawan hukum sehingga yang dapat merugikan pemegang saham minoritas, antara lain: ${ }^{5}$

Pertama, Direksi melakukan transaksi self dealing dan ajaran corporate opportunity. Pengertian transaksi self dealing adalah suatu transaksi yang dilakukan oleh direksi secara pribadi, baik secara langsung maupun tidak langsung dengan perusahaan yang dipimpinnya sebagai pihak lawan transaksi. Transaksi untuk pribadi ini merupakan perwujudan

\footnotetext{
${ }^{5}$ Rachmadi Usman, Dimensi Hukum Perusahaan Perseroan Terbatas, Alumni, Bandung, 2004, h. 123-124.
}

dari transaksi yang melekat kepentingan (interested transaction) oleh Direksi suatu Perseroan yang merupakan suatu transaksi yang dilakukan oleh Direksi (langsung atau tidak langsung) dengan Perseroan itu sendiri. Transaksi self dealing disini mengandung unsur conflict of interest, yaitu antara kepentingan pribadi Direksi dengan kepentingan Perseroan, sehingga hal ini dapat merugikan Perseroan maupun pemegang saham minoritas. Sedangkan ajaran corporate opportunity menyatakan bahwa Direksi maupun organ Perseroan lainnya tidak diperbolehkan mengambil kesempatan untuk memperoleh keuntungan untuk dirinya sendiri, jika kesempatan tersebut sebenarnya dapat diberikan kepada Perseroan.

Kedua, Melakukan transfer keuntungan yang diperoleh oleh satu anak perusahaan ke anak perusahaan lainnya, seperti dengan melakukan transaksi pembelian yang mahal atau sebaliknya dengan penjualan yang murah antar anak perusahaan atau melakukan kegiatan yang menguntungkan pada satu anak perusahaan yang dialihkan kepada anak perusahaan yang lain dan dana dari anak perusahaan tersebut digunakan untuk mengatasi krisis keuntungan anak perusahaan yang lain yang mengalami kerugian karena kegiatan yang secara ekonomis tidak dapat dipertanggungjawabkan, dan Direksi melakukan tindakan tersebut tanpa persetujuan dari RUPS. Ketiga, Mengambil atau menggelapkan sebagian keuntungan perusahaan untuk kepentingan pribadi.

Keempat, Pemberian kredit kepada pihak lain tanpa analisa kredit yang baik meskipun permohonan kredit tersebut sebenarnya tidak layak (feasible), tetapi direksi akan memutuskan untuk memberikan kredit yang dimohon, tanpa adanya persetujuan dari Komisaris maupun RUPS dan ternyata kemudian kredit menjadi macet yang sangat merugikan Perseroan. Kelima, Memberikan keterangan dan pernyataan yang tidak benar dan/atau menyesatkan.

\section{Akibat Hukum bagi Direksi Perseroan yang Melakukan Perbuatan Melawan Hukum}

Direksi dalam melaksanakan kewenangannya menjalankan pengurusan Perseroan harus demi kepentingan Perseroan dan tidak boleh untuk kepentingan pribadi. Kewenangan pengurusan tersebut tidak mengandung benturan kepentingan (conflict of interest), tidak mempergunakan kekayaan, 
milik atau uang Perseroan untuk kepentingan pribadi, tidak boleh mempergunakan posisi jabatan Direksi yang dipangkunya untuk memperoleh keuntungan pribadi dan tidak menahan atau mengambil sebagian keuntungan Perseroan untuk kepentingan pribadi.

Tindakan yang bertentangan dengan kepentingan Perseroan, dapat dikategorikan melanggar batas kewenangan atau kapasitas pengurusan. Perbuatan itu dapat dikualifikasi menyalahgunakan kewenangan (abuse of authority), atau mengandung ultra vires. Menurut ketentuan Pasal 97 ayat (1) UUPT menegaskan bahwa Direksi bertanggungjawab atas pengurusan Perseroan. Dan selanjutnya di dalam Pasal 92 ayat (2) dinyatakan bahwa pengurusan sebagaimana dimaksud, wajib dilaksanakan oleh setiap anggota Direksi dengan itikad baik dan penuh tanggung jawab. Dan Pasal 97 ayat (3) menegaskan bahwa, setiap anggota Direksi bertanggungjawab penuh secara pribadi atas kerugian Perseroan apabila yang bersangkutan bersalah atau lalai menjalankan tugasnya sesuai dengan ketentuan.

Hal ini berarti bahwa anggota Direksi wajib melaksanakan tugasnya dengan itikad baik (in good faith) dan dengan penuh tanggung jawab (and with full sense of responsibility). Selama hal tersebut dijalankan, para anggota Direksi tetap mempunyai tanggung jawab yang terbatas yang merupakan ciri utama dari suatu Perseroan. Namun apabila hal tersebut dilanggar, maka karena "unsur kesalahan atau kelalaian" yaitu adanya benturan kepentingan transaksi tertentu menjadi ukuran bagi Direksi untuk dapat dimintai pertanggungjawaban secara pribadi atas kerugian yang diderita Perseroan.

Hal-hal yang bisa membuat direksi dimintai pertanggungjawaban secara pribadi atas kerugian PT antara lain sebagai berikut: ${ }^{6}$ pertama, Direksi tidak melaksanakan fiduciary duty kepada Perseroan; kedua, Laporan Keuangan PT yang tidak benar dan/atau menyesatkan; ketiga, PT pailit karena kesalahan atau kelalaian Direksi; keempat, Anggota Direksi tidak melaporkan kepemilikan saham oleh anggota Direksi yang bersangkutan dan/atau keluarganya dalam PT sehingga anggota Direksi yang bersangkutan bertanggungjawab secara pribadi sesuai Pasal 101 ayat (1) dan (2) UUPT menegaskan

${ }^{6}$ Hadi, Zarman, Karakteristik Tanggung Jawab Pribadi Pemegang Saham, Komisaris dan Direksi dalam Perseroan Terbatas, Universitas Brawijaya Press (UB Press), Malang, 2011, h. 116. bahwa: a. Anggota Direksi wajib melaporkan kepada Perseroan mengenai saham yang dimiliki anggota Direksi yang bersangkutan dan/atau keluarganya dalam Perseroan dan Perseroan lain untuk selanjutnya dicatat dalam daftar khusus; b. Anggota Direksi yang tidak melaksanakan kewajiban dan menimbulkan kerugian bagi Perseroan, bertanggungjawab secara pribadi atas kerugian Perseroan tersebut.

Dengan demikian akibat hukum bagi Direksi Perseroan yang melakukan perbuatan melawan hukum harus bertanggungjawab secara pribadi, sehingga pemegang saham minoritas dapat mengajukan gugatan kepada Direksi Perseroan, sebagaimana diatur dalam Pasal 97 ayat (6) UUPT menyatakan bahwa, atas nama Perseroan, pemegang saham yang mewakili paling sedikit 1/10 (satu per sepuluh) bagian dari jumlah seluruh saham dengan hak suara dapat mengajukan gugatan melalui Pengadilan Negeri.

Tanggung jawab Direksi akibat perbuatan melawan hukum Direksi selain diatur dalam UUPT tidak mengurangi ketentuan diatur dalam UndangUndang tentang Hukum Pidana, karena memenuhi unsur: ${ }^{7}$

Pertama, Direksi dapat terbukti melakukan penggelapan uang Perseroan, maka Direksi dapat dikenai sanksi sebagaimana diatur dalam Pasal 372 Kitab Undang-Undang Hukum Pidana (selanjutnya disebut KUHP), yaitu barangsiapa dengan sengaja dan melawan hukum memiliki barang sesuatu yang seluruhnya atau sebagian adalah kepunyaan orang lain, tetapi yang ada dalam kekuasaannya bukan karena kejahatan diancam karena penggelapan, dengan pidana penjara paling lama empat tahun atau pidana denda paling banyak sembilan ratus rupiah.

Kedua, Direksi terbukti melakukan Penipuan, yaitu tindakan untuk menguntungkan diri sendiri atau orang lain, dengan memberikan keterangan dan pernyataan yang tidak benar dan/atau menyesatkan, sehingga Direksi dapat dikenai sanksi berdasarkan Pasal 378 KUHP yang menyatakan barangsiapa dengan maksud untuk menguntungkan diri sendiri atau orang lain secara melawan hukum, dengan memakai nama palsu atau martabat palsu, dengan tipu muslihat, atau pun rangkaian kebohongan, menggerakkan orang lain untuk menyerahkan barang sesuatu kepadanya, atau supaya memberi hutang maupun menghapuskan piutang, diancam

\footnotetext{
${ }^{7}$ Pasal 155 UUPT.
} 
karena penipuan dengan pidana penjara paling lama empat tahun.

\section{Upaya Pemegang Saham Minoritas menurut UUPT}

Berdasarkan pada Pasal 138 ayat (1) UUPT menegaskan bahwa pemegang saham minoritas, dapat mengajukan permohonan supaya diadakan pemeriksaan atas Perseroan, atas dugaan Direksi Perseroan yang melakukan perbuatan melawan hukum, yang bertujuan untuk memperoleh data dan keterangan dari Perseroan, sehubungan dengan dugaan: pertama, Perseroan melakukan perbuatan melawan hukum yang merugikan pemegang saham atau pihak ketiga; atau kedua, anggota Direksi atau Dewan Komisaris melakukan perbuatan melawan hukum yang merugikan Perseroan atau pemegang saham atau pihak ketiga.

Data atau keterangan yang dicari dan diperoleh dari hasil pemeriksaan untuk dijadikan sebagai bukti yang dapat memperjelas tentang benar atau tidaknya dugaan perbuatan melawan hukum yang dilakukan oleh Direksi, apabila hasil dari pemeriksaan tersebut ditemukan fakta-fakta tentang terjadinya perbuatan melawan hukum, maka hasil pemeriksaan tersebut dapat digunakan sebagai bukti yang menyatakan bahwa Direksi telah melakukan perbuatan melawan hukum.

Pada Pasal 173 HIR, yang menegaskan bahwa, Persangkaan saja yang tidak berdasarkan suatu peraturan undang-undang yang tertentu, hanya harus diperhatikan oleh hakim waktu menjatuhkan keputusan jika persangkaan itu penting, seksama, tertentu, dan satu sama lain bersetujuan. Dari ketentuan tersebut dapat disimpulkan bahwa ada dua macam persangkaan, yaitu persangkaan saja yang sifatnya sama dengan isyarat atau penunjukan, yang tidak lain daripada kesimpulan-kesimpulan yang diambil oleh hakim dari suatu kejadian atau keadaan yang telah terbukti, dan persangkaan berdasarkan undang-undang. ${ }^{8}$

Menurut Pasal 1915 KUHPerdata ditegaskan bahwa persangkaan-persangkaan ialah kesimpulankesimpulan yang oleh undang-undang atau oleh hakim ditariknya dari suatu peristiwa yang terkenal ke arah suatu peristiwa yang tidak terkenal. Dua macam persangkaan, yaitu: persangkaan menurut undang-

${ }^{8}$ Soesilo, RIB/HIR dengan Penjelasan, Politeia, Bogor, 1995, h. 127. undang dan persangkaan yang tidak berdasarkan undang-undang. Pada Pasal 1916 KUHPerdata menegaskan bahwa persangkaan-persangkaan menurut undang-undang ialah persangkaan yang berdasarkan suatu ketentuan khusus undang-undang, dihubungkan dengan perbuatan-perbuatan tertentu atau peristiwa-peristiwa tertentu.

Dugaan atau persangkaan yang memiliki kualitas sebagai alat bukti sah, dugaan itu harus merupakan kesimpulan yang ditarik dari suatu peristiwa, suatu hal atau tindakan yang terjadi, dan dari kesimpulan yang ditarik itu ditemukan indikasi atau fakta adanya unsur Perbuatan Melawan Hukum yang dilakukan Direksi. Dugaan yang memenuhi syarat untuk mengajukan permintaan minimal harus ada pembuktian yang diperlukan pemeriksaan terhadap Perseroan untuk memperoleh alat bukti yang sah baik berupa dokumen, keterangan saksi atau ahli, sebagai persiapan untuk mengajukan gugatan Perbuatan Melawan Hukum berdasar Pasal 1365 KUHPerdata terhadap Direksi. ${ }^{9}$

Sedangkan yang dapat mengajukan permohonan pemeriksaan tersebut, berdasar Pasal 138 ayat (3) UUPT adalah: a. Satu pemegang saham atau lebih yang mewakili paling sedikit $1 / 10$ bagian dari jumlah seluruh saham dengan hak suara; b. Pihak lain yang berdasarkan: peraturan perundang-undangan, anggaran dasar Perseroan atau perjanjian dengan Perseroan diberi wewenang untuk mengajukan permohonan pemeriksaan; atau c. Kejaksaan untuk kepentingan umum.

Sebelum mengajukan permohonan untuk dilakukannya pemeriksaan terhadap Perseroan, pemegang saham atau pihak yang berkepentingan harus terlebih dahulu telah meminta data dan keterangan yang diperlukan langsung kepada Perseroan dalam RUPS. Dan jika Perseroan tidak memberi data dan keterangan yang diminta tersebut, maka pemeriksaan dapat diajukan ke Pengadilan Negeri.

Selain itu permohonan pemeriksaan tersebut harus didasarkan atas alasan yang wajar dan itikad baik didasarkan pada Pasal 138 ayat (5) UUPT, apabila menurut pertimbangan Ketua Pengadilan Negeri permohonan yang diajukan tidak didasarkan atas alasan yang wajar dan/atau tidak dengan itikad baik didasarkan pada Pasal 139 ayat (2) UUPT,

9 Yahya Harahap, Hukum Perseroan Terbatas, Sinar Grafika, Jakarta, 2009, h. 527-528. 
maka Ketua Pengadilan Negeri berhak untuk menolak permohonan tersebut, begitu sebaliknya apabila Pengadilan memandang bahwa permohonan pemeriksaan tersebut memang didasarkan pada alasan yang wajar dan dengan itikad baik, maka Ketua Pengadilan Negeri dapat mengabulkan permohonan tersebut dengan mengeluarkan penetapan untuk pemeriksaan.

Adapun isi pokok penetapan yang dikeluarkan oleh Ketua Pengadilan Negeri tersebut harus memuat diktum: a. Mengabulkan permohonan pemeriksaan terhadap Perseroan; b. Mengangkat ahli (paling banyak 3 (tiga) orang) untuk melakukan pemeriksaan terhadap Perseroan; c. Menetapkan jangka waktu pemeriksaan paling lambat 90 (sembilan puluh) hari terhitung sejak tanggal pengangkatan; d. Memerintahkan ahli membuat dan menyampaikan Laporan Hasil Pemeriksaan kepada Ketua Pengadilan Negeri dalam jangka tertentu, tidak boleh lewat dari 90 (sembilan puluh) hari; dan e. Menetapkan atau menentukan biaya pemeriksaan. ${ }^{10}$

Dan dalam pemeriksaan tersebut juga diangkat ahli, yaitu paling banyak tiga orang ahli, dimana ditentukan oleh undang-undang, menurut penjelasan Pasal 139 ayat (3) bahwa ahli merupakan orang yang mempunyai keahlian dalam bidang yang akan diperiksa, dimana keahlian tersebut meliputi kecakapan (skill) yang diperoleh dari hasil pendidikan (education) atau latihan (training) maupun hasil pengalaman (experience), sehingga keterangan dan pendapat yang disampaikan dapat melebihi kemampuan pengetahuan atau pengalaman orang biasa. Dalam Pasal 139 ayat (1) UUPT menegaskan bahwa tidak semua dapat diangkat sebagai ahli, diantaranya setiap anggota Direksi, setiap anggota Dewan Komisaris, karyawan Perseroan, Konsultan, dan Akuntan Publik yang telah ditunjuk oleh Perseroan, karena mereka dianggap mempunyai benturan kepentingan dengan Perseroan.

Adapun yang harus diperiksa oleh pemeriksa adalah semua dokumen yang berkaitan dengan Perseroan, seperti buku-buku, catatan dan suratsurat yang berkaitan dengan kegiatan Perseroan didasarkan atas Pasal 139 ayat (5) UUPT, dan kekayaan Perseroan yang dianggap perlu untuk diketahui, oleh karena itu semua karyawan, Direksi dan Komisaris wajib memberikan segala keterangan yang diperlukan untuk pelaksanaan pemeriksaan.

${ }^{10}$ Ibid., h. 536-527.
Pada Pasal 140 ayat (1) UUPT menegaskan bahwa apabila setelah dilakukan pemeriksaan, pemeriksa wajib untuk membuat laporan hasil pemeriksaan, dan pemeriksa tidak boleh mengumumkan hasil pemeriksaan tersebut kepada pihak lain, akan tetapi harus disampaikan kepada Ketua Pengadilan Negeri dalam jangka waktu paling lama 90 (sembilan puluh) hari, dan juga selambatnya 14 (empat belas) hari terhitung sejak tanggal laporan hasil pemeriksaan diterima, Ketua Pengadilan Negeri harus memberikan salinan laporan hasil pemeriksaan kepada pemohon (pemegang saham minoritas) dan Perseroan yang bersangkutan dilandaskan pada Pasal 140 ayat (2) UUPT.

Sedangkan mengenai hal biaya pemeriksaan, Ketua Pengadilan Negeri menentukan jumlah maksimum biaya pemeriksaan yang akan dibayar oleh Perseroan dilandaskan pada Pasal 141 ayat (1) dan ayat (2) UUPT yang berdasarkan atas keahlian pemeriksaan dan batas kemampuan Perseroan. Namun apabila terdapat Perseroan yang mengajukan permohonan pemeriksaan, maka pembebanan biaya dibayar seluruhnya oleh Perseroan, sebagaimana diatur dalam 141 ayat (3) UUPT, yaitu Ketua Pengadilan Negeri atas permohonan Perseroan dapat membebankan penggantian seluruh atau sebagian biaya pemeriksaan sebagaimana dimaksud pada ayat (2) kepada pemohon, anggota Direksi, dan/atau anggota Dewan Komisaris.

Berlandaskan pada Pasal 97 ayat (6) UUPT, Laporan Hasil Pemeriksaan tersebut menjadi bahan pertimbangan bagi pemohon (pemegang saham minoritas) untuk dapat menentukan sikap, apakah pemohon (pemegang saham minoritas) tersebut akan mengajukan gugatan kepada Direksi Perseroan.

\section{PENUTUP \\ Kesimpulan}

Berdasarkan permasalahan sebagaimana bab sebelumnya, maka dapat ditarik kesimpulan bahwa perlindungan hukum bagi pemegang saham minoritas dapat dicapai dengan terpenuhinya unsur keadilan, diperlukan suatu keseimbangan sehingga pihak pemegang saham minoritas tetap dapat menikmati haknya selaku mayoritas, termasuk mengatur Perseroan. Di lain pihak, pihak pemegang saham minoritas pun perlu diperhatikan kepentingannya dan tidak bisa begitu saja diabaikan haknya. Untuk menjaga kepentingan di kedua belah pihak, dalam 
ilmu hukum Perseroan dikenal prinsip Majority Rule minority Protection, yaitu yang memerintah (the ruler) di dalam Perseroan tetap pihak mayoritas, tetapi kekuasaan pihak mayoritas tersebut haruslah dijalankan dengan selalu melindungi (to protect) pihak minoritas. Hal ini jika tidak mendapatkan perhatian dari pemerintah di khawatirkan akan mengganggu iklim investasi dan mematikan investorinvestor kecil, Di samping itu Perseroan harus menerapkan prinsip Good Corporate Governance agar dapat mengatur perilaku Direksi, Dewan Komisaris maupun Manajer, dengan merinci tugas dan wewenang serta pertanggungjawaban kepada pemegang saham.

Akibat perbuatan melawan hukum Direksi, maka harus bertanggungjawab untuk mengganti kerugian yang timbul (Pasal 1365 KUHPerdata) dan jika ditemukan adanya unsur pidana, yaitu adanya pengelapan uang dan penipuan, Direksi dapat dikenai pidana penjara maupun pidana denda (Pasal 372 dan Pasal 378 KUHP) bahkan Direksi dapat bertanggungjawab sampai harta pribadinya (Pasal 97 ayat (3) UUPT).

Upaya pemegang saham minoritas menurut UUPT dengan mengajukan permohonan untuk diadakan pemeriksaan atas Perseroan (Pasal 138 ayat (1) UUPT) serta dapat mengajukan gugatan terhadap Direksi melalui Pengadilan Negeri yang daerah hukumnya meliputi tempat kedudukan Perseroan. Gugatan terhadap Direksi diajukan karena kesalahan atau kelalaian Direksi yang menimbulkan kerugian pada Perseroan, agar Perseroan menghentikan tindakan Direksi yang merugikan dan mengambil langkah-langkah, baik untuk mengatasi akibat yang sudah timbul maupun untuk mencegah tindakan serupa di kemudian hari.

\section{Rekomendasi}

Pemegang saham minoritas dari PT, hak dan kewajibannya sebenarnya tidak ada perbedaannya dengan hak dan kewajiban pemegang saham mayoritas, asalkan sesuai dengan syarat yang telah digariskan dalam Pasal 97 ayat (3) UUPT.

\section{DAFTAR PUSTAKA}

\section{Peraturan Perundang-undangan:}

Kitab Undang-Undang Hukum Perdata (Burgerlik van Wetboek/BW).

Kitab Undang-Undang Hukum Pidana (Wetboek van Staafrecht $/ \mathrm{WvS}$ ).

Undang-Undang Nomor 40 Tahun 2007 tentang Perseroan Terbatas, Lembaran Negara Republik Indonesia Tahun 2007 Nomor 106, Tambahan Lembaran Negara Republik Indonesia Nomor 4756.

\section{Buku:}

Badrulzaman, Mariam Darus, Sutan Remy Sjahdeini, Heru Soepraptomo, Faturrahman Djamil, dan Taryana Soenandar. 2001. Kompilasi Hukum Perikatan, Dalam Rangka Memperingati Memasuki Masa Purna Bakti Usia 70 Tahun. Bandung: Citra Aditya Bakti.

Chatamarrasjid, 1990. Menyingkap Tabir Perseroan (Piercing The Corporate Veil) Kapita Selekta Hukum Perusahaan. Bandung: Citra Aditya Bakti.

Hadi, Zarman. 2011. Karakteristik Tanggung Jawab Pribadi Pemegang Saham, Komisaris dan Direksi dalam Perseroan Terbatas. Malang: Universitas Brawijaya Press (UB Press).

Harahap, Yahya. 2009. Hukum Perseroan Terbatas. Jakarta: Sinar Grafika.

Soesilo. 1995. RIB/HIR dengan Penjelasan. Bogor: Politeia.

Usman, Rachmadi. 2004. Dimensi Hukum Perusahaan Perseroan Terbatas. Bandung: Alumni.

\section{Website:}

http://id.wikipedia.org/wiki/Pemegang_saham, diunduh pada hari Rabu tanggal 16 April 2014 pukul 20.50 WIB. 